\title{
ASSESSMENT OF THE EFFECT OF MONOHYDROXY ALCOHOLS, UNSATURATED FATTY ACIDS, ORGANOPHOSPHATE COMPOUNDS ON THE ENZYMATIC ATP-HYDROLYSIS IN THE CELL MEMBRANES OF THE SMOOTH MUSCLE OF THE RAT COLON
}

\author{
A. A. KAPLIA ${ }^{\bowtie}$, S. V. MIDYK ${ }^{1}$, S. V. KHYZHNYAK ${ }^{1}$ \\ ${ }^{1}$ National University of Life and Environmental Sciences of Ukraine, Kyiv; \\ 凶e-mail: kaplyaalex@gmail.com
}

The differences of the structural-functional stability of ATP-hydrolases to the action of the short-chain aliphatic monohydroxy alcohols and long-chain unsaturated fatty acids (UFAs) with wide range of the membrane-acting effectiveness were evaluated in the colonic smooth muscle (CSM) cellular membranes. It was shown that $\mathrm{Mg}^{2+}, \mathrm{ATP}$-hydrolase was more resistant to all tested aliphatic compounds than $\mathrm{Na}^{+}, \mathrm{K}^{+}$-ATPase. There was a clear relationship between inhibitory efficiency, chain length (number of carbons) increase and relative polarity decrease in the series of straight-chain alcohols. Secondary alcohol 2-propanol turned out to be the weaker inhibitor than primary alcohol 1-propanol. The $I_{50}$ value ( $\mathrm{MM}$ ) for ATPases decreased in the following succession: ethanol > 2-propanol > 1-propanol > 1-butanol. UFAs were the stronger inhibitors $\left(I_{50}\right.$ of $\mu M$ range) than alcohols ( $\mathrm{mM}$ range). Oleic acid inhibited $\mathrm{Na}^{+}, \mathrm{K}^{+}$-ATPase with lower efficiency than was detected for arachidonic acid according to the differences in double bonds number; $\mathrm{I}_{50}$ for $\mathrm{Mg}^{2+}$, ATP-hydrolase activity was the same for studied UFAs. As well, the organophosphate pesticide fenamiphos proved to be a weak ATPase inhibitor. Comparison of the enzymatic pair of the CSM ATP-hydrolases seems applicable for evaluation of the specific membrane-acting effect of bioactive compounds on $\mathrm{Na}^{+}, \mathrm{K}^{+}$-ATPase activity from the standpoint of its role in mediating of electro-mechanical coupling in intestinal smooth muscles.

Keywords: ATP-hydrolases, $\mathrm{Na}^{+}, \mathrm{K}^{+}$-ATPase, colonic smooth muscle, aliphatic monohydroxy alcohols, unsaturated fatty acids, organophosphate compounds, fenamiphos.

$\mathrm{Na}^{+}, \mathrm{K}^{+}$-ATPase (EC 3.6.3.9) is the molecular representation of the electrogenic $\mathrm{Na}^{+}, \mathrm{K}^{+}$-pump in the plasma membrane of animal cells. Smooth muscle contraction relies on the activity of the $\mathrm{Na}^{+}, \mathrm{K}^{+}-$ ATPase, which maintains electrochemical gradient of the sodium and potassium ions across the plasma membrane, powered by ATP, that drive excitationcontraction coupling [1-3]. Actually, membrane potential of smooth muscles, including gastrointestinal muscles, is important because it controls voltage dependent $\mathrm{Ca}^{2+}$-channels thereby regulating $\left[\mathrm{Ca}^{2+}\right]_{\mathrm{i}}$, which triggers contraction [4]. Thus, depolarization of the membrane by $\sim 15 \mathrm{mV}$ from its resting potential (approximately -50 to $-40 \mathrm{mV}$ ) elevates $\left[\mathrm{Ca}^{2+}\right]_{\mathrm{i}}$ to $\sim 300-400 \mathrm{nM}$, whereas hyperpolarization by $\sim 15 \mathrm{mV}$ lowers $\left[\mathrm{Ca}^{2+}\right]_{\mathrm{i}}$ to $\sim 100 \mathrm{nM}[5]$.
Being electrogenic, $\mathrm{Na}^{+}, \mathrm{K}^{+}$-pump contributes to the setting of the resting membrane potential. The magnitude of sodium pump-dependent increment of the resting potential varies at different smooth muscles and even their areas. Really, in the circular layer of canine colonic smooth muscle the resting potential gradient was detected. The cells at the submucosal border generate approximately $35 \mathrm{mV}$ of pump potential, whereas at the myenteric border the pump contributes very little to resting potential [6]. It was also found, that pump-dependent increment of the resting potential was determined by $\mathrm{Na}^{+}, \mathrm{K}^{+}$-ATPase $\alpha 1$-isoform level which expression varied at the circular muscle layer with mRNA and protein twice as abundant in submucosal border muscle, decreasing in the direction to the myenteric border muscle [7].

(C) 2018 Kaplia A. A. et al. This is an open-access article distributed under the terms of the Creative Commons Attribution License, which permits unrestricted use, distribution, and reproduction in any medium, provided the original author and source are credited. 
It is considered that the concentration gradient of sodium pump is a molecular basis of the resting potential gradient, existing across circular muscle layer. The discrepancy in resting potential on both muscle borders is completely eliminated by $\mathrm{Na}^{+}, \mathrm{K}^{+}-$ ATPase inhibition by cardioactive steroids, which cause membrane depolarization. It is suggested that the resting potential gradient may contribute, at least partly, to electrical and mechanical dissimilarity of colonic circular smooth muscle and other regions of gastro-intestinal tract. It was shown that the maintenance of the stable $\mathrm{Na}^{+}, \mathrm{K}^{+}$-ATPase expression in cultured tissue retained unchanged resting membrane potential in submucosal surface of circular smooth muscle during the culture period and protected against the increase of the sensitivity in contractile response to acetylcholine [8]. Evidently, an increased $\mathrm{Na}^{+}, \mathrm{K}^{+}$-ATPase content, which provides the highest resting potential at the muscle lumenal border of colon may contribute to stabilization and control of the electrical and contractile activity of the selective submucosal muscle region. It can also have a pathophysiological relevance.

Therefore, $\mathrm{Na}^{+}, \mathrm{K}^{+}$-ATPase functioning, significantly contributing to the regulation of resting potentials, mediates excitability and electro-mechanical coupling in colonic smooth muscle (CSM). It can be expected that $\mathrm{Na}^{+}, \mathrm{K}^{+}$-ATPase defect occurring under pathological sarcollemmal impairment can contribute to colonic smooth muscle cell dysfunction. Contrariwise, functional alteration in CSM can be manifested by significant changes in cell membrane properties which affect the $\mathrm{Na}^{+}, \mathrm{K}^{+}$-ATPase activity. Really, the abnormal intestinal motility in inflammatory bowel disease is accompanied both by mucosal impairment and coupled decrease of $\mathrm{Na}^{+}, \mathrm{K}^{+}$-ATPase activity, relative ionic and osmotic disbalance in epithelial cells and the functional failure of smooth muscle cells, including changes in the activity of muscarinic receptors, ion channels in sarcolemma, etc. $[9,10]$.

In this context, the membrane-dependent structure-function relationship of the CSM Na${ }^{+}, \mathrm{K}^{+}$ATPase is of particular interest. It should be noted, that rat CSM $\alpha 1$-isoform of $\mathrm{Na}^{+}, \mathrm{K}^{+}$-ATPase belongs to low ouabain affinity particular enzymatic type of rodents [11]. It is well accepted that the activity of membrane proteins such as $\mathrm{Na}^{+}, \mathrm{K}^{+}$-ATPase strongly depends on the surrounding lipid environment. Currently, the understanding is being formed how transmembrane proteins can in turn influence the organization of lipids in biomembranes [12]. Earlier, we proposed that peculiarities of the membrane stability of the $\mathrm{Na}^{+}, \mathrm{K}^{+}$-ATPase catalytic subunit isoforms in the brain and kidney were due to the specificity of the boundary lipids [13]. Presently it is found that the specific protein-lipid interactions in several sites with lipids, including cholesterol, bound in pockets between transmembrane domains, may play a physiological role regulating the activity and stability of the pump [14].

An important tool for the study of the membrane integral properties of the membrane-bound enzymes, such as ATPases, are inhibitors - modifiers of specific functional groups or intramolecular and intermolecular interactions in the membrane. They serve as direct or indirect indicators of certain structural and functional relations, namely, the conformational stability of enzymes in the membrane as a result of the catalytic cycle specifics, its sensitivity to disorganization of the membrane surrounding or modification of the lipid matrix, packaging of the annular and specific lipids. More informative is a comparative study of the influence of the modifiers with a predicted membrane action on different enzymatic systems of the ATP-hydrolysis with principally different catalytic mechanism and structural organization, viz, P-type $\mathrm{Na}^{+}, \mathrm{K}^{+}$-ATPase vs ouabaininsensitive $\mathrm{Mg}^{2+}$-ATP-hydrolase. This research considering the recent data [15] educes and broadens understanding of the features that determine the specific effects on ATP-hydrolases of two groups of the aliphatic compounds: short-chain monohydroxy alcohols and unsaturated fatty acids (UFAs).

Thus, the aim of this study is to compare the relative structure-function resistance in membrane of the ATPases $\left(\mathrm{Na}^{+}, \mathrm{K}^{+}\right.$-ATPase vs $\mathrm{Mg}^{2+}$-ATPase), affected by the solvents and lipophilic modifiers: primary and secondary alcohols (1-propanol and 2-propanol) and oleic acid (OlA), to determine their efficiency in a series of aliphatic compounds differed by polarity, hidrofobicity and number of the double bond [15]. In addition, a standardized approach is applied for evaluation of the action of biologically active compounds on the example of an organophosphate insecticide fenamiphos (FP) or ethyl 3-methyl4-(methylsulfanyl)phenyl isopropylphosphoramidate (ACD/IUPAC Name).

\section{Materials and Methods}

The isolation of the nonmitochondrial membrane fraction from rat CSM, protein concentration, 
membrane permeabilization by Ds-Na pretreatment, ATPase activities and inorganic phosphate were determined as described earlier [13, 15]. Male Wistar rats were fed with the standard diet of the vivarium and deprived of food the day before the experiment. Animals were anesthetized by diethyl ether inhalation and decapitated. The experiments were done in accordance with bioethics guidelines for work with laboratory animals declared in the European Convention for the Protection of Vertebrate Animals Used for Experimental and Other Scientific Purposes (Strasbourg, 1986).

The $\mathrm{Na}^{+}, \mathrm{K}^{+}$-ATRase and $\mathrm{Mg}^{2+}$,ATP-hydrolase were differentiated by the sensitivity to $1 \mathrm{mM}$ ouabain as the components of the total ATPase activity in disrupted membrane vesicle preparations. The pretreatment conditions were as follows: $0.04 \%$ Ds$\mathrm{Na}$ (detergent/protein ratio $=0.2$ at $23{ }^{\circ} \mathrm{C}, 30 \mathrm{~min}$ ) in the medium, contained: $30 \mathrm{mM}$ tris- $\mathrm{HCl}$ buffer (pH 7.54), $0.16 \mathrm{M}$ sucrose, additionally $1 \mathrm{mM}$ EGTA and $3 \mathrm{mM}$ ATP. $\mathrm{Na}_{2}$ (for catalytic cite protection), $2 \mathrm{mg} / \mathrm{ml}$ protein, $0.4 \mathrm{mg} / \mathrm{ml}$ Ds-Na. The treatment was terminated by dilution $1 / 10$ by chilled $30 \mathrm{mM}$ tris- $\mathrm{HCl}$ buffer ( $\mathrm{pH}$ 7.54) with $1 \mathrm{mM}$ EGTA and $3 \mathrm{mM}$ ATP $\cdot \mathrm{Na}_{2}$. Aliquots of 50-60 $\mu \mathrm{l}$ were added into ATPase reaction mixture $(0.5 \mathrm{ml})$ at $37^{\circ} \mathrm{C}$. Final detergent dilution was 80-100 times. The membrane pretreatment with Ds-Na according to Jorgensen and Sweadner procedure for excitable tissues, kidney, etc., used for CSM membranes, is based on the precautions, noted earlier $[13,15]$. It allows measuring relatively high for crude smooth muscle membranes the latent $\mathrm{Na}^{+}, \mathrm{K}^{+}$-ATPase activity of functional protein-lipid complexes of enzymes at optimal protein/ Ds-Na pretreatment, but at insignificant detergent concentration in the incubation mixture. Ds- $\mathrm{Na}$ is used instead of cholesterol-selective detergent digitonin [16]. The effect of the modifiers on the ATPhydrolase activities were estimated in enzyme pair: $\mathrm{Na}^{+}, \mathrm{K}^{+}$-ATPase vs ouabain-insensitive $\mathrm{Mg}^{2+}$,ATP-hydrolase. The inhibitory efficiency as an indicator of the inhibitor functional activity was evaluated based on the inhibition coefficients $\left(I_{50}\right)$ calculated for enzymatic dose-inhibition curves in Hill equations. OlA and FP solutions were prepared on DMSO. In the control samples, the corresponding amount of DMSO without the modifier was added. The $0.5 \%$ DMSO concentration in the incubation mixture did not alter the enzymatic activities. The agents in appropriate controls did not affect the color intensity by Chen (the formation of phosphomolybdate in the presence of ascorbate) under ten times dilution at staining, had no effect on the spontaneous hydrolysis of ATP and during detergent pretreatment, did not cause turbidity when using solubilizing concentrations of Ds-Na to stop the reaction.

Statistical analysis of the results was performed using Microsoft Office Excell 2007 and OriginPro 9.0. The data are given as means \pm SEM. The significance of statistical differences between two groups was evaluated using Student's $t$-test $(P<0.05)$.

In the study the following reagents were used: ATP $\cdot \mathrm{Na}_{2}$, EGTA, oleic acid, ouabain, DMSO, fenamiphos (Sigma, USA), EDTA (Fluka, Switzerland), Ds-Na (Serva, Germany) and other chemicals were of chemically pure grade of local production.

\section{Results and Discussion}

The features of the modulation of ATP enzymatic hydrolysis by modifiers of intra-protein and intermolecular protein-lipid interactions with different hydrophobicity were further examined in the rat CSM membranes. At first the effect was compared in the simplest pair of the primary and secondary alcohols: 1-propanol and its isomer isopropanol (Fig. 1). Thus, for both ATP-hydrolases the primary alcohol 1-propanol revealed higher inhibition efficiency in comparison with the secondary alcohol 2-propanol. In general, the relative inhibitory pattern of these aliphatic monohydroxy alcohols for the studied ATP-hydrolases corresponded to that previously established for ethanol and 1-butanol [15]. The data of inhibitory efficiency of the short-chain aliphatic monohydroxy alcohols and their polarity characteristics are summarized in Table $1[15,17-$ 19]. A decrease in the $I_{50}$ value corresponds to an increase in the sensitivity to inhibition. In every case of the tested series the $\mathrm{Na}^{+}, \mathrm{K}^{+}$-ATPase is more sensitive to inhibition than $\mathrm{Mg}^{2+}$-ATPase. The inhibition coefficient value, $I_{50}$, of each short-chain alcohol is 3-4 times lower for ion-transporting ATPase than $\mathrm{Mg}^{2+}$,ATP-hydrolase, respectively. The differences in $\mathrm{I}_{50}$ values for alcohols are statistically significant between two distinct enzymes and between the effects of the separate alcohols in the series on the same enzyme (Table 1). For isopropanol and 1-propanol $I_{50}$ values were intermediate between the values for ethanol and 1-butanol.

In fact, the inhibitory efficiency of short-chain alcohols tested in our study increased sharply in the following order: ethanol $<2$-propanol $<1$-propanol 


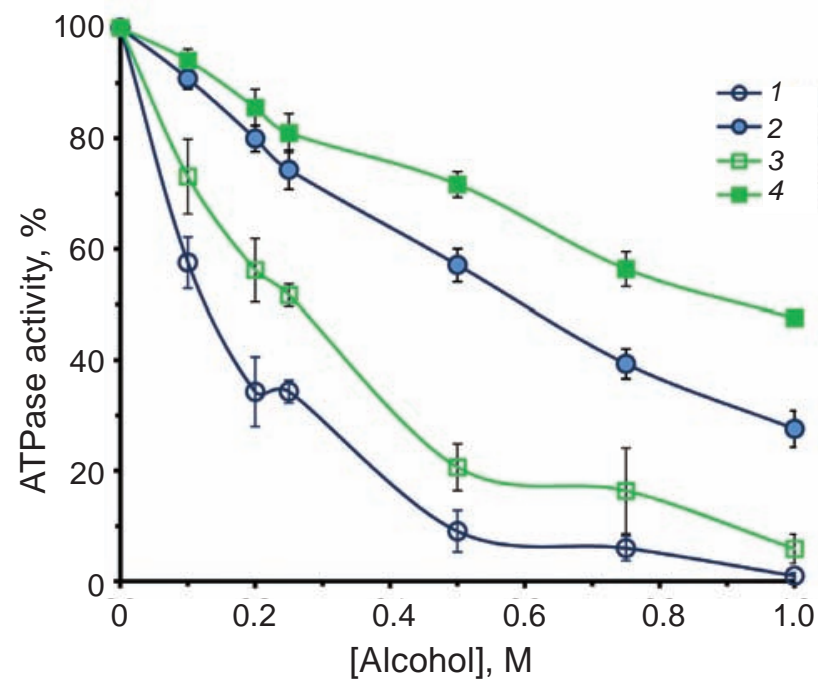

Fig. 1. The effect of 1-propanol $(1,2)$ and 2-propanol $(3,4)$ on rat CSM $\mathrm{Na}^{+}, \mathrm{K}^{+}$-ATPase $(1,3)$ and $\mathrm{Mg}^{2+}$ ATPase $(2,4)(M \pm m, n=4) .100 \%$ - corresponding activity without alcohol

$<$ 1-butanol. As shown, despite the same number of carbon atoms, isopropanol is a less effective inhibitor than 1-propanol. Thus, as can be seen from Table 1, a clear relationship of the inhibition efficiency increase ( $\mathrm{I}_{50}$ value decrease) with increasing number of carbons (chain length) exists only for straight-chain alcohols. This also coincides with a decrease in the polarity indexes of the solvents and concomitant hydrophobicity increase of hydrocarbon straight-chain of alcohols [20]. The hydrophobicity of such molecules increases with longer contiguous chains of hydrocarbons. At the same time, in the series including the secondary alcohol 2-propanol, the dependence of the ATPase inhibition efficiency on the relative polarity of the alcohol is not apparent. It can be assumed, that the inhibitory potency of the short-chain aliphatic alcohols is dependent both on the chain length and the structure along with radical hydrophobicity, namely in the carbon atoms number order, Cn: $2<2+1<3<4$.

The action of short-chain alcohols is believed to result from nonspecific interactions with biomembranes altering the function of membranebound proteins as well as $\mathrm{Na}^{+}, \mathrm{K}^{+}$-ATPase [21]. A relationship between chain length (per every $\mathrm{CH}_{2}$ group increase), lipid solubility of a series of shortchain aliphatic alcohols, chain length-dependent effects on membrane structural physical and chemical properties and their relative inhibitory effects on membrane-bound enzymes was demonstrated in a number of membrane systems. The dependence between the ability to alter plasma membrane integrity and their hydrophobicity in such series of alcohols suggests that similar structure-activity relationships exist at both mild and moderate levels of membrane disruption [20]. It appears, however, that $\mathrm{Na}^{+}, \mathrm{K}^{+}$ATPase inhibition in neuronal membranes is not completely dependent on alcohol interaction with membrane lipids; the direct interaction of alcohol with the enzyme protein may also be involved in the inhibition [22]. Our previous results support a view that alcohol absorbs into the bilayer headgroup region, with enhanced partitioning as the chain-length of the alcohol increases [23, 24]. Perturbation by the alcohol molecules partitioned into the headgroup region is stronger than the disordering effect caused by the alcohol chain in the hydrocarbon region [25]. Besides, branched molecules may have differential solubilities in membranes of different composition, that cannot always be predicted from octanol:water partition coefficients because branched molecules

Ta ble 1. Inhibition parameters for ATP-hydrolases by simplest aliphatic monohydroxy alcohols and their polarity characteristics as protic solvents $\left(I_{50}: M \pm m, n=4-5\right)$

\begin{tabular}{l|c|c|c|c|c|c}
\hline Alcohol & Formula & $\begin{array}{c}\mathrm{Na}^{+}, \mathrm{K}^{+} \text {-ATPase, } \\
\mathrm{I}_{50}, \mathrm{mM}\end{array}$ & $\begin{array}{c}\mathrm{Mg}^{2+} \text {-ATPase, } \\
\mathrm{I}_{50}, \mathrm{mM}\end{array}$ & $\begin{array}{c}\text { Relative } \\
\text { polarity [17 }\end{array}$ & $\begin{array}{c}\text { Snyder } \\
\text { polarity } \\
\text { index [18] }\end{array}$ & $\begin{array}{c}\text { Dielectric } \\
\text { constant } \\
\left(20^{\circ} \mathrm{C}\right)[19]\end{array}$ \\
\hline Ethanol\& & $\mathrm{C}_{2} \mathrm{H}_{6} \mathrm{O}$ & $606.96 \pm 40.38^{*}$ & $1775.02 \pm 198.26$ & 0.654 & 5.2 & 22.4 \\
1-propanol & $\mathrm{C}_{3} \mathrm{H}_{8} \mathrm{O}$ & $129.14 \pm 23.19^{*}, \#$ & $549.49 \pm 51.21^{\#}$ & 0.617 & 4.3 & 20.1 \\
2-propanol & $\mathrm{C}_{3} \mathrm{H}_{8} \mathrm{O}$ & $250.61 \pm 19.64^{*}$ & $1020.06 \pm 85.32$ & 0.546 & 4.3 & 18.3 \\
1-butanol\& & $\mathrm{C}_{4} \mathrm{H}_{10} \mathrm{O}$ & $79.52 \pm 1.35^{*}$ & $234.26 \pm 6.83$ & 0.586 & 3.9 & 18.2 \\
\hline
\end{tabular}

* Significant differences vs corresponding $\mathrm{Mg}^{2+}$-ATPase activity, ${ }^{\#}$ vs isopropanol). ${ }^{\&} \mathrm{I}_{50}$ values according to [15]; ${ }^{\circledR}$ The values for relative polarity are normalized from measurements of solvent shifts of absorption spectra (for $\left.\mathrm{H}_{2} \mathrm{O}=1\right)$ [17] 
are differentially excluded from structured bilayers [26]. In particular, 2-propanol was revealed not to be as effective in decreasing the interfacial tension as 1-propanol in aqueous mixtures because it partitions poorly to the surface due to its larger excluded volume [27]. Anyway, differences in molecular structuring in the membrane surface region may be responsible for the weaker inhibitory effect on $\mathrm{Na}^{+}, \mathrm{K}^{+}$-ATPase of 2-propanol in comparison with 1-propanol in our study.

It is natural, that ion-transporting ATPase, $\mathrm{Na}^{+}, \mathrm{K}^{+}$-ATPase in particular, appeared to be highly susceptible to membrane disturbance induced by alcohols in colonic CSM membrane preparations. Certainly, the cyclic intramolecular conformational transitions in the process of the catalytic turnover require highly coordinated protein-protein and protein-lipid interactions supported by lipid microenvironment. As well, the greater resistance of the $\mathrm{Mg}^{2+}$-ATP-hydrolase activity in comparison with $\mathrm{Na}^{+}, \mathrm{K}^{+}$-ATPase to aliphatic alcohols may indicate differences of the structural and functional organization of these ATP-hydrolytic enzymes in the membrane, their distinct localization and dependence on the native lipid environment for their functional activity.

In further experiments the effect of OlA (18:1, ๑-9) on CSM ATP-hydrolases was studied (Fig. 2). It is a monounsaturated fatty acid, belonging to $₫-9$ UFAs family. In comparative researches arachidonic acid, AA (20:4, ๓-6) - polyunsaturated $₫-6$ fatty acid was used [15]. UFAs represent another group of the highly lipophilic aliphatic compounds of physiological relevance with different metabolic significance $[15,28,29]$. The inhibitory efficiency of OlA on ATPases in the membrane preparations was much higher than for alcohols, $\mathrm{I}_{50}$ value shifted into micromolar concentration range (Table 2). However, differences in sensitivity to inhibition by UFAs remain significant for different ATP-hydrolases as in the case of alcohols: higher for $\mathrm{Na}^{+}, \mathrm{K}^{+}$-ATPase in comparison with $\mathrm{Mg}^{2+}$-ATPase. Taking into account the previous studies [15], CSM Na+, $\mathrm{K}^{+}$-ATPase is somewhat less sensitive to inhibition by OlA than by AA. $\mathrm{I}_{50}$ values for $\mathrm{Na}^{+}, \mathrm{K}^{+}$-ATPase inhibition differ significantly, 3.2 times, between two UFAs, while $\mathrm{I}_{50}$ for $\mathrm{Mg}^{2+}$-ATPase vs $\mathrm{Na}^{+}, \mathrm{K}^{+}$-ATPase is 2.8 and 7.8 times higher for OlA and AA, respectively. First of all, the features of UFAs action coincide with the difference between the two UFAs in the degree of unsaturation, preferable to the number of carbon atoms

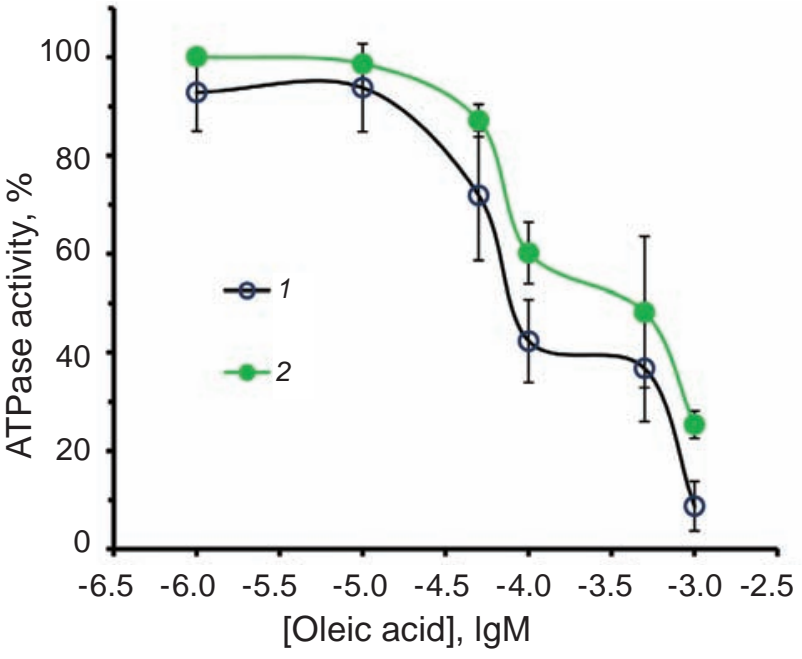

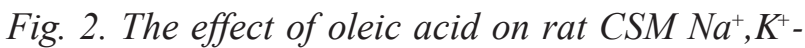
ATPase (1) and $\mathrm{Mg}^{2+}$-ATPase (2) activity ( $M \pm m$, $n=4-5) .100 \%$ - corresponding activity without effectors

(the length of the aliphatic radical). At the same time $\mathrm{Mg}^{2+}$-ATPase sensitivity to both UFAs was similar in our experiments (Table 2). It is well known that sensitivity to inhibition of $\mathrm{Na}^{+}, \mathrm{K}^{+}$-ATPase in membrane preparations by free fatty acid increased as the number of double bonds increased [30]. On the contrary, saturated and methylated fatty acids had little or no effect on $\mathrm{Na}^{+}, \mathrm{K}^{+}$-ATPase [28].

The presented results for OlA and AA may indicate that two long-chain fatty acids show different disturbing efficiency of the functional conformation of the $\mathrm{Na}^{+}, \mathrm{K}^{+}$-ATPase, maintained by lipid surrounding. Apparently, it may be a consequence of the differences in the UFAs physical-chemical proper-

Ta ble 2. Inhibition parameters $\left(I_{50}, \mu M\right)$ for CSM ATP-hydrolases by the biologically active compounds: long-chain unsaturated fatty acids and organophosphate pesticide fenamiphos $(M \pm m$, $n=4-5$ )

\begin{tabular}{l|c|c}
\hline $\begin{array}{c}\text { Compound, } \\
\mathrm{I}_{50}, \mu \mathrm{M}\end{array}$ & $\mathrm{Na}^{+}, \mathrm{K}^{+}$-ATPase & $\mathrm{Mg}^{2+}$-ATPase \\
\hline $\begin{array}{l}\text { Oleic acid } \\
\text { Arachidonic }\end{array}$ & $97.55 \pm 23.02^{*, \#}$ & $277.50 \pm 63.60$ \\
$\begin{array}{l}\text { acid [15] } \\
\text { Fenamiphos }\end{array}$ & $680.55 \pm 4.37^{*, \#}$ & $237.87 \pm 43.35$ \\
\hline
\end{tabular}

* Significant differences vs corresponding $\mathrm{Mg}^{2+}$-ATPase activity, " between fatty acids 
ties, determined by chain length, structure, number and location of double-bonds, hydrophobicity of aliphatic radical in particular. This effect is more subtly manifested for ion-transporting ATPase than for $\mathrm{Mg}^{2+}$-ATPase. It may reflect the enzyme differences in binding capacities for UFAs, determined by structural differences, membrane organization of two enzymes and/or their lipid dependence. It has been found in other studies that $\mathrm{Na}^{+}, \mathrm{K}^{+}$-ATPase is able to bind directly with OlA up to more than 100 mol per mol of $\alpha \beta$-oligomer enzyme. Binding of UFAs to $\mathrm{Na}^{+}, \mathrm{K}^{+}$-ATPase lead to its inhibition and modulation of the certain partial enzymatic reactions [28, 29].

It is generally accepted, that the functional stability of the integral membrane protein such as $\mathrm{Na}^{+}, \mathrm{K}^{+}$-ATPase depends strongly on the surrounding lipids, which are important to sustain the folded protein conformation in membrane necessary for manifestation of high enzymatic activity. Moreover, it is proposed that specific protein-lipid interactions in pockets between transmembrane domains are physiologically important for controlling of the enzymatic functional stability [14]. In these experiments the procedure according to Jorgensen and Sweadner with mild Ds-Na pretreatment of membrane vesicles was used for $\mathrm{Na}^{+}, \mathrm{K}^{+}$-ATPase activity detection in CSM membrane fraction as described earlier [13, 15]. Also, selective detergent-cholesterol interaction, known for digitonin [16], is excluded. It enables to preserve the enzymatic protein-lipid complexes in fragmented membranes, at least, with boundary lipids, which are essential to maintain folded functional enzyme conformation, not achieving uncontrolled solubilization of the membrane components.

According to $\mathrm{Na}^{+}, \mathrm{K}^{+}$-ATPase structure its molecule includes ten transmembrane hydrophobic segments connected with extramembrane loops more protruding into cytoplasm, especially the catalytic loop between 4-5 transmembrane spans [31]. The ability to perform sequential cooperative interactions during conformational rearrangement of functional domains in the mechanism of $\mathrm{Na}^{+}, \mathrm{K}^{+}$-ATPase catalytic turnover, required to transfer (occlusion-deocclusion) $\mathrm{Na}^{+}$and $\mathrm{K}^{+}$ions, is determined by correctly folded enzyme molecule, which is controlled by boundary lipids. Just such conformational transitions may be sensitive targets to the disturbance by modifiers of the protein-lipid and protein-protein interactions in protein-lipid ensemble of $\mathrm{Na}^{+}, \mathrm{K}^{+}$-ATPase.

Summarizing the data presented in Table 1 and 2 the comparison of the $I_{50}$ values in two groups of the aliphatic compounds may indicate the substantial increase of their apparent affinity for ATP-hydrolases from high millimolar to micromolar range in the succession: short-chain monohydroxy alcohols - UFAs. For straight-chain alcohols it can be accounted for the concomitant chain-length-dependent increase of hydrophobicity. The secondary alcohol 2-propanol complicates this dependence presumably due to its anomalous behavior in aqueous solutions. Thus, for $\mathrm{Na}^{+}, \mathrm{K}^{+}$-ATPase the $\mathrm{I}_{50}$ value decreases in the order: ethanol > 2-propanol > 1-propanol > 1-butanol >> $\mathrm{OlA}>\mathrm{AA}$. The same order of $\mathrm{I}_{50}$ values is revealed for $\mathrm{Mg}^{2+}$-ATPase, except for UFAs: OlA = AA.

Not considering the concrete binding sites the presented results revealed the disturbing efficiency of the compounds on membrane enzymatic complexes indicating higher resistance of $\mathrm{Mg}^{2+}$-ATP-

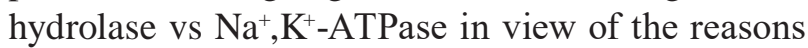
discussed above. The highest sensitivity of $\mathrm{Na}^{+}, \mathrm{K}^{+}-$ ATPase $\left(\mathrm{I}_{50} \sim 30 \mu \mathrm{M}\right)$ was demonstrated for AA in vitro. Monounsaturated fatty acid OlA had lower sensitivity with $\mathrm{I}_{50} \sim 100 \mu \mathrm{M}$. Questionable, whether such an order of magnitude of the apparent affinity approaches physiologically significant values, considering the existence of multiple metabolic and regulatory pathways involving UFAs? By the way, it is observed an unrelated equivalence to the inhibitory parameters of flavonolignans, recently characterized as a novel class of sodium pump inhibitors with the action mechanism distinct from that of cardiac glycosides [32].

Actually, $I_{50}$ values can serve for relative evaluation of the inhibitory effectiveness of the potential membrane-acting agent on membrane-bound ATP-hydrolases in comparison with standardized potency of the aliphatic compounds with predicted mechanism of action. Besides, for estimation of inhibitory activity of membrane-acting agent it is important to study not the only effect on a single $\mathrm{Na}^{+}, \mathrm{K}^{+}$-ATPase activity but compare specificity to ATP-hydrolases with different mechanism of ATP hydrolysis.

Thus, considering the previous data [15, 23, 33] the differences in $\mathrm{I}_{50}$ for CSM ATPases are revealed for SH-reagents, oxidants, heavy metals due to enzymatic specificity in SH-importance and sensitivity to POL. Herein, the specific inhibitory effect of the hydrophobic agents (aliphatic compounds: alcohols, UFAs), which are the modifiers of the membrane surface region, protein molecule itself and boundary lipids, is also shown for two modes of ATP-hydroly- 
sis. It may be the distinctive unfolding effect on the enzyme functional conformation due to the different structure-function relationship of ATP-hydrolases in membranes. Naturally, the catalytic turnover of iontransporting ATPase proved to be the sensitive target for membrane-acting agents affecting protein-lipid complexes.

The purpose of the further research was to evaluate the features of actions of the biologically active substances on ATP-hydrolases by the example of commonly used pesticide fenamiphos (FP) with the standard mechanism of cytotoxic action for this group of substances. It is an organophosphate insecticide with chemical name: ethyl 3-methyl4-(methylsulfanyl)phenyl isopropylphosphoramidate. As it is shown (Fig. 3, Table 2), FP reveals itself as a weak nonselective inhibitor, affecting ATPases in a indiscriminate way. $\mathrm{I}_{50}$ values are not statistically different both for $\mathrm{Na}^{+}, \mathrm{K}^{+}$-ATPase and $\mathrm{Mg}^{2+}$-ATPase. At concentrations below $100 \mu \mathrm{M}$ FM does not affect the ATPase activities. The FM molecule contains ethyl and isopropyl radicals, but FP inhibitory effectiveness is much higher than for individual aliphatic alcohols, and $\mathrm{I}_{50}$ decreases to high micromolar values. The compound demonstrates the inhibitory pattern for ATPases different from the effects of the hydrophobic aliphatic agents and oxidants [15, 33]. Thus, the inhibitory effect may be determined by the complex nature of FP molecule, but differences in specific action (according to the apparent affinity index) for the two types of ATPase are lost. It can be noted, however, that at $1 \mathrm{mM}$ concentration of FP the resistant component of $\mathrm{Mg}^{2+}$-ATPase activity (up to $40 \%$ of residual activity) is preserved. Despite the lack of selectivity, the data indicate, obviously, a similar mechanism of FP action in accordance with the general properties of the enzymes in the interaction with substrate and ATP hydrolysis.

FP exerts its toxic effect through acetyl cholinesterase (ACHE) inhibition. Interestingly, that being specific nematicide, FP blocks ACHE activity of nematodes (the target pest) in vitro with $\mathrm{I}_{50}=555 \mu \mathrm{M}$ [34], comparable with our results on CSM ATPase inhibition. Nevertheless, FP is a highly toxic compound. The mechanism of the toxicity of organophosphorus insecticides to non-target organisms, including humans, is manifested also by the ACHE inhibition [35, 36]. It is shown that ACHE blocking by different organophosphate insecticides is a result of specific phosphorylation or carbamylation of hydroxyl in serine residue in enzyme active sites.

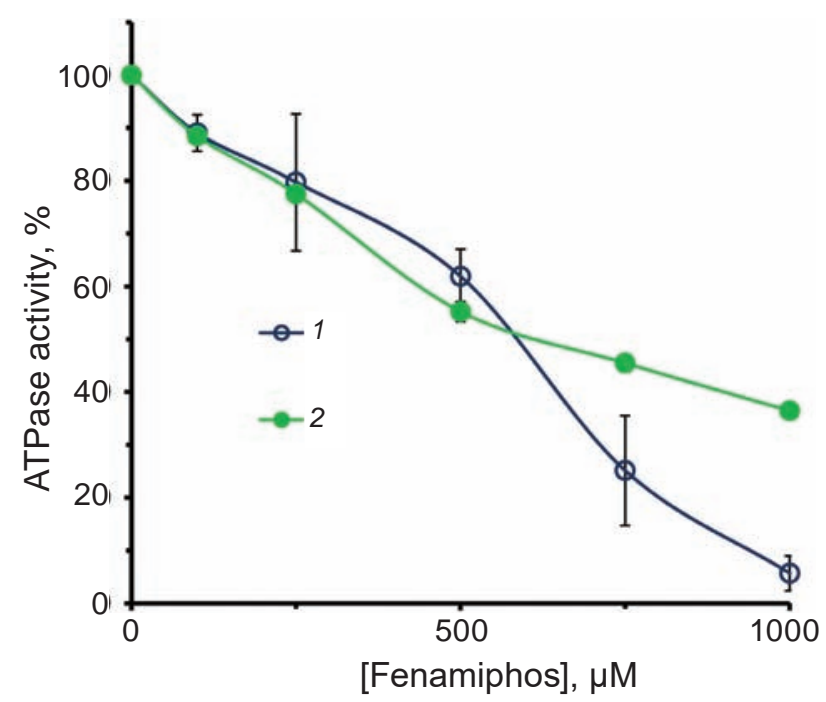

Fig. 3. The effect of fenamiphos on rat $\mathrm{CSM} \mathrm{Na}^{+}, \mathrm{K}^{+}$ATPase (1) and $\mathrm{Mg}^{2+}$-ATPase (2) activity ( $M \pm m$, $n=4) .100 \%$-corresponding activity without agent

Likewise, it is of interest to ascertain if the modification of certain amino acids can determine the inhibition of ATPase? Physiological importance of low affinity ATPase inhibition by FP is questionable. The other biochemical FP targets are also known, including muscarinic acetylcholine receptors, mitochondrial ATPase, ets. Nevertheless, it is established that FP is a weak ATPase inhibitor. Certainly, these data expand understanding of the biochemical properties of FP.

Therefore, to evaluate the effectiveness of the membrane-acting agent, the test significance has not only the determination of the inhibitory effectiveness on the P-type ATPase, namely $\mathrm{Na}^{+}, \mathrm{K}^{+}$-ATPase, but the comparative effect on ATP-hydrolase systems with a different mechanism of ATP hydrolysis. The relative structural stability of ATP-hydrolases was first evaluated in CSM membranes; it was based on the relative sensitivity to inhibition by the lipophilic modifiers with anticipated mechanism of action, such as simplest aliphatic monohydroxy alcohols and long-chain UFAs, allowing to set a rather wide range of the membrane-acting efficiency. Data suggest the differences in the structural-functional stability in the membrane of two ATPases. Inhibitory potency depends on the chain length, increasing in the series of short-chain monohydroxy alcohols, or unsaturation index for UFAs. For primary alcohols, the inhibitory efficiency increases with decreasing polarity. The inhibition efficiency of monohydroxy alcohols and UFAs may indicate the intensity of the 
impairing effect by aliphatic agents and target importance for the structural-functional stability of the membrane protein-lipid ATPase complexes. Characterization of the organophosphate insecticide FP as weak ATPase inhibitor opens a prospect to evaluate the membrane-acting behavior of a lot of other bioactive and toxic compounds on the $\mathrm{Na}^{+}, \mathrm{K}^{+}$-ATPase activity in CSM membranes. A comparison of the enzymatic pair of the CSM ATP-hydrolases seems applicable for evaluation of the specific membraneacting effect of a bioactive compounds on $\mathrm{Na}^{+}, \mathrm{K}^{+}-$ ATPase activity from the standpoint of its role in mediating of electro-mechanical coupling in intestinal smooth muscles.

\section{ОЦНКА ВПЛИВУ ОДНОАТОМНИХ СПИРТІВ, НЕНАСИЧЕНИХ ЖИРНИХ КИСЛОТ, ФОСФОРОРГАНІЧНИХ СПОЛУК НА ЕНЗИМАТИЧНИЙ ГІДРОЛІЗ АТР У КЛІТИННИХ МЕМБРАНАХ ГЛАДЕНЬКОГО М'ЯЗА ОБОДОВОЇ КИШКИ ЩУРА}

\section{О. А. Капля ${ }^{\bowtie}$, С. В. Мідик' , С. В. Хижняк ${ }^{1}$}

${ }^{1}$ Національний університет біоресурсів та природокористування України, Київ;

e-mail: kaplyaalex@gmail.com

Відмінності структурно-функціональної стійкості АТР-гідролаз до дії коротколанцюгових аліфатичних одноатомних спиртів і довголанцюгових ненасичених жирних кислот (НЖК) із широким діапазоном за ефективністю мембранотропної дії було оцінено в клітинних мембранах гладких м'язів ободової кишки (ГМОК) щура. Показано, що $\mathrm{Mg}^{2+}$, АТРгідролаза $є$ більш стійкою до дії досліджуваних аліфатичних сполук, ніж $\mathrm{Na}^{+}, \mathrm{K}^{+}$-АТРаза. Спостерігався чіткий зв'язок між збільшенням ефективності інгібування 3 довжиною ланцюга (кількістю атомів вуглецю) і зменшенням відносної полярності в ряду первинних спиртів. Вторинний спирт 2-пропанол виявився слабшим інгібітором, ніж первинний спирт 1-пропанол. Величина $\mathrm{I}_{50}$ (мM) зменшувалася в такій послідовності для АТРаз: етанол $>$ 2-пропанол > 1-пропанол > 1-бутанол. НЖК були значно сильнішими інгібіторами (мкM діапазон $\mathrm{I}_{50}$ ), ніж спирти (мМ діапазон). Олеїнова кислота інгібувала $\mathrm{Na}^{+}, \mathrm{K}^{+}$-АТРазу 3 більш низькою ефективністю, ніж було виявлено для арахідонової кислоти відповідно до відмінностей в числі подвійних зв'язків; $\mathrm{I}_{50}$

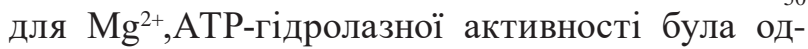
наковою для досліджених НЖК. Крім того, фосфорорганічний пестицид фенаміфос виявився слабким інгібітором АТРаз. Порівняння в ензимній парі АТР-гідролаз ГМОК може бути застосовано для оцінки ефективності мембранотропної дії біологічно активних сполук на активність $\mathrm{Na}^{+}, \mathrm{K}^{+}$-АТРази 3 точки зору її опосередкованої участі в модуляції електромеханічного спряження в гладеньких м'язах кишечника.

Ключ ов і слов а: АТР-гідролази, $\mathrm{Na}^{+}, \mathrm{K}^{+}$-АТРаза, гладенький м'яз ободової кишки, аліфатичні одноатомні спирти, ненасичені жирні кислоти, фосфорорганічні сполуки, фенаміфос.

\section{ОЦЕНКА ВЛИЯНИЯ \\ ОДНОАТОМНЫХ СПИРТОВ, НЕНАСЫЩЕННЫХ ЖИРНЫХ КИСЛОТ, ФОСФОРОРГАНИЧЕСКИХ СОЕДИНЕНИЙ НА \\ ЭНЗИМАТИЧЕСКИЙ ГИДРОЛИЗ АТР В КЛЕТОЧНЫХ МЕМБРАНАХ ГЛАДКОЙ МЫШЦЫ ОБОДОЧНОЙ КИШКИ КРЫСЫ}

\section{А. А. Капля ${ }^{凶}$, С. В. МидькК, С. В. Хижняк ${ }^{1}$ \\ ${ }^{1}$ Национальный университет биоресурсов и природопользования Украины, Киев; 凶e-mail: kaplyaalex@gmail.com}

Различия структурно-функциональной устойчивости АТР-гидролаз к действию короткоцепочечных алифатических одноатомных спиртов и длинноцепочечных ненасыщенных жирных кислот (НЖК) с широким диапазоном по эффективности мембранотропного действия были оценены в клеточных мембранах гладких мышц ободочной кишки (ГМОК) крысы. Показано, что $\mathrm{Mg}^{2+}$,АТР-гидролаза более устойчива к действию исследуемых алифатических соединений, чем $\mathrm{Na}^{+}, \mathrm{K}^{+}$-АТРаза. Наблюдалась четкая связь между увеличением эффективности ингибирования с длиной цепи (количеством атомов углерода) и уменьшением относительной полярности в ряду первичных спиртов. Вторичный спирт 2-пропанол оказался более слабым ингибитором, чем первичный спирт 1-пропанол. 
Величина $\mathrm{I}_{50}(\mathrm{MM})$ уменьшалась в следующей последовательности для АТРаз: этанол > 2-пропанол > 1-пропанол > 1-бутанол. НЖК были более сильными ингибиторами (мкМ диапазон $\left.\mathrm{I}_{50}\right)$, чем спирты (мМ диапазон). Олеиновая кислота ингибировала $\mathrm{Na}^{+}, \mathrm{K}^{+}$-АТРазу с более низкой эффективностью, чем было обнаружено для арахидоновой кислоты в соответствии с различиями в числе двойных связей; $\mathrm{I}_{50}$ для $\mathrm{Mg}^{2+}$, АТРгидролазной активности была одинаковой для изученных НЖК. Кроме того, фосфорорганический пестицид фенамифос оказался слабым ингибитором АТРаз. Сравнение в энзимной паре АТР-гидролаз ГМОК представляется применимой для оценки эффективности мембранотропного действия биологически активных соединений на активность $\mathrm{Na}^{+}, \mathrm{K}^{+}$-АТРазы с точки зрения ее опосредованного участия в модуляции электромеханического сопряжения в гладких мышцах кишечника.

К л ю че вы е с ло в а: АТР-гидролазы, $\mathrm{Na}^{+}, \mathrm{K}^{+}$-АТРаза, гладкая мышца ободочной кишки, алифатические одноатомные спирты, ненасыщенные жирные кислоты, фосфорорганические соединения, фенамифос.

\section{References}

1. Clausen MV, Hilbers F, Poulsen H. The Structure and Function of the Na,K-ATPase Isoforms in Health and Disease. Front Physiol. 2017; 8: 371.

2. Floyd RV, Mobasheri A, Wray S. Gestation changes sodium pump isoform expression, leading to changes in ouabain sensitivity, contractility, and intracellular calcium in rat uterus. Physiol Rep. 2017; 5(23): e13527.

3. Kosterin SA. Calcium transport in smooth muscle. Kiev: Naukova Dumka, 1990. 216 p. (In Russian).

4. Huang X, Lee SH, Lu H, Sanders KM, Koh SD. Molecular and functional characterization of inwardly rectifying $\mathrm{K}^{+}$currents in murine proximal colon. J Physiol. 2018; 596(3): 379-391.

5. Hill-Eubanks DC, Werner ME, Heppner TJ, Nelson MT. Calcium signaling in smooth muscle. Cold Spring Harb Perspect Biol. 2011; 3(9): a004549.

6. Burke EP, Sanders KM. Effects of ouabain on background and voltage-dependent currents in canine colonic myocytes. Am J Physiol. 1990; 259(3 Pt 1): C402-C408.
7. Burke EP, Sanders KM, Horowitz B. Sodium pump isozymes are differentially expressed in electrically dissimilar regions of colonic circular smooth muscle. Proc Natl Acad Sci USA. 1991; 88(6): 2370-2374.

8. Horner MJ, Ward SM, Gerthoffer WT, Sanders KM, Horowitz B. Maintenance of morphology and function of canine proximal colon smooth muscle in organ culture. Am $J$ Physiol. 1997; 272(3 Pt 1): G669-G680.

9. Allgayer H, Kruis W, Paumgartner G, Wiebecke B, Brown L, Erdmann E. Inverse relationship between colonic $\left(\mathrm{N}^{\mathrm{a}^{+}}+\mathrm{K}^{+}\right)$-ATPase activity and degree of mucosal inflammation in inflammatory bowel disease. Dig Dis Sci. 1988; 33(4): 417-422.

10. Ohama T, Hori M, Ozaki H. Mechanism of abnormal intestinal motility in inflammatory bowel disease: how smooth muscle contraction is reduced? J Smooth Muscle Res. 2007; 43(2): 43-54.

11. Kaplia AA. The heterogeneity of the $\mathrm{Na}^{+}, \mathrm{K}^{+}-$ ATPase ouabain sensitivity in microsomal membranes of rat colon smooth muscles. $U \mathrm{kr}$ Biokhim Zhurn. 2011; 83(5): 89-93. (In Russian).

12. Nyholm TK. Lipid-protein interplay and lateral organization in biomembranes. Chem Phys Lipids. 2015; 189: 48-55.

13. Kaplya A, Kravtsova VV, Kravtsov AV. Inactivation of brain $\mathrm{Na}^{+}, \mathrm{K}^{+}$-ATPase catalytic subunit isoforms by sodium dodecyl sulfate. Membr Cell Biol. 1997; 11(1): 87-99.

14. Habeck M, Haviv H, Katz A, Kapri-Pardes E, Ayciriex S, Shevchenko A, Ogawa H, Toyoshima C, Karlish SJ. Stimulation, inhibition, or stabilization of Na,K-ATPase caused by specific lipid interactions at distinct sites. $J$ Biol Chem. 2015; 290(8): 4829-4842.

15. Kaplia AA. Different sensitivity of $\mathrm{Na}^{+}, \mathrm{K}^{+}-$ ATPase and $\mathrm{Mg}^{2+}$-ATPase to ethanol and arachidonic acid in rat colon smooth muscle under pretreatment of cellular membranes with Ds-Na. Ukr Biochem J. 2017; 89(2): 70-77.

16. Sudji IR, Subburaj Y, Frenkel N, García-Sáez AJ, Wink M. Membrane Disintegration Caused by the Steroid Saponin Digitonin Is Related to the Presence of Cholesterol. Molecules. 2015; 20(11): 20146-20160. 
17. Reichardt C. Solvents and Solvent Effects in Organic Chemistry. Wiley-VCH Publishers, $3^{\text {rd }}$ ed., 2003; 653 p.

18. Snyder LR. Classification of the solvent properties of common liquids. J Chromatography A. 1974; 92(2): 223-230.

19. Smallwood IM. Handbook of organic solvent properties. UK, 2012; 306 p.

20. McKarns SC, Hansch C, Caldwell WS, Morgan WT, Moore SK, Doolittle DJ. Correlation between hydrophobicity of shortchain aliphatic alcohols and their ability to alter plasma membrane integrity. Fundam Appl Toxicol. 1997; 36(1): 62-70.

21. Valentine WM. Toxicology of selected pesticides, drugs, and chemicals. Short-chain alcohols. Vet Clin North Am Small Anim Pract. 1990; 20(2): 515-523.

22. Nhamburo PT, Salafsky BP, Hoffman PL, Tabakoff B. Effects of short-chain alcohols and norepinephrine on brain $\left(\mathrm{Na}^{+}, \mathrm{K}^{+}\right)$ATPase activity. Biochem Pharmacol. 1986; 35(12): 1987-1992.

23. Mishchuk DO, Kaplia AA. Effect of ethanol on structural and functional characteristics of rat brain cortical membranes in vitro. Ukr Biokhim Zhurn. 2003; 75(2): 55-61. (In Russian).

24. Ly HV, Longo ML. The influence of short-chain alcohols on interfacial tension, mechanical properties, area/molecule, and permeability of fluid lipid bilayers. Biophys J. 2004; 87(2): 10131033.

25. Löbbecke L, Cevc G. Effects of short-chain alcohols on the phase behavior and interdigitation of phosphatidylcholine bilayer membranes. Biochim Biophys Acta. 1995; 1237(1): 59-69.

26. Goldstein DB. The effects of drugs on membrane fluidity. Annu Rev Pharmacol Toxicol. 1984; 24: 43-64.

27. Ballal D, Chapman WG. Hydrophobic and hydrophilic interactions in aqueous mixtures of alcohols at a hydrophobic surface. $J$ Chem Phys. 2013; 139(11): 114706.
28. Swarts HG, Schuurmans Stekhoven FM, De Pont JJ. Binding of unsaturated fatty acids to $\mathrm{Na}^{+}, \mathrm{K}^{+}$-ATPase leading to inhibition and inactivation. Biochim Biophys Acta. 1990; 1024(1): 32-40.

29. Mahmmoud YA, Christensen SB. Oleic and linoleic acids are active principles in Nigella sativa and stabilize an E(2)P conformation of the $\mathrm{Na}, \mathrm{K}-\mathrm{ATPase}$. Fatty acids differentially regulate cardiac glycoside interaction with the pump. Biochim Biophys Acta. 2011; 1808(10): 24132420.

30. Swann AC. Free fatty acids and $\left(\mathrm{Na}^{+}, \mathrm{K}^{+}\right)$ATPase: effects on cation regulation, enzyme conformation, and interactions with ethanol. Arch Biochem Biophys. 1984; 233(2): 354-361.

31. Jorgensen PL, Hakansson KO, Karlish SJ. Structure and mechanism of Na,K-ATPase: functional sites and their interactions. Annu Rev Physiol. 2003; 65: 817-849.

32. Kubala M, Čechová P, Geletičová J, Biler M, Štenclová T, Trouillas P, Biedermann D. Flavonolignans as a novel class of sodium pump inhibitors. Front Physiol. 2016; 7: 115.

33. Kaplia AA. The influence of heavy metal ions, spermine and sodium nitroprusside on ATPhydrolases of cell membranes of rat colon smooth muscle. Ukr Biochem J. 2016; 88(4): 20-28.

34. Nordmeyer D, Dickson DW. Biological activity and acetylcholinesterase inhibition by nonfumigant nematicides and their degradation products on Meloidogyne incognit. Revue Nématol. 1990; 13(2): 229-232.

35. Sánchez-Bayo F. Insecticides mode of action in relation to their toxicity to non-target organisms. J Environ Anal Toxicol. 2012; S4: 002.

36. Kharchenko OA, Balan GM, Bubalo NM. Acute Organophosphate Poisoning: the Main Clinical Syndromes and the Mechanisms of their Formation (Literature Review and the Data of Own Research). Modern Probl Toxicol. 2013; (12): 17-31. 